\title{
Cardiovascular Applications of Stem Cell Therapy
}

Soheil Sadri', Ramesh Mazhari ${ }^{2}$, Maziar Sadri², Nahal Konjedi ${ }^{1}$, and Palak Shah ${ }^{2 *}$

${ }^{1}$ Division of Genomic Medicine, USA

${ }^{2}$ Division of Cardiology, George Washington University, Washington DC, USA

\begin{abstract}
Despite remarkable progress in medical and surgical therapy for heart disease, congestive heart failure (CHF) and coronary artery disease (CAD) are leading causes of morbidity and mortality in the United States. Although implantation of a left ventricular assist device has recently emerged as a promising therapy for CHF, no other therapy holds as much promise for the treatment of patients suffering from cardiovascular disease other than cardiac regeneration. In this regard, there are substantial pre-clinical and clinical studies that have elucidated the safety and efficacy of cardiac stem cell-based therapy using a variety of cell lines to promote regeneration of the heart. In spite of promising results in both animal and human studies, the exact fate of these administered stem cells within the human heart is poorly understood as is the mechanism by which they promote myocardial recovery and regeneration. These limitations of our current knowledge base can be considered a critical issue limiting widespread application of stem cell-based therapy.
\end{abstract}

Keywords: Stem cells; Congestive heart failure; Coronary artery disease; Cardiac regeneration

\section{Introduction}

One of the most common causes of death worldwide is acute myocardial infarction (AMI). The end-stage sequela of adverse remodeling after AMI is congestive heart failure (CHF). In spite of valid therapeutic advances in the last half century, $\mathrm{CHF}$ continues to be the leading cause of hospitalization for people aged 65 years and older [1]. According to the American Heart Association, CHF is estimated to affect 4.8 million Americans each year with an estimated total cost of $\$ 39.2$ billion in 2010 [2]. CHF is responsible for a significant decrease in physical and mental health, the end result of which is a clearly noticeable decreased quality of life $[3,4]$.

AMI is associated with a loss of cardiomyocytes and this process was traditionally believed to be permanent as the heart was traditionally considered to be a terminally differentiated organ [5]. In the last decade, this paradigm has been challenged as different types of stem cells have been used for the purpose of cardiac regeneration including skeletal myoblasts, bone marrow derived mononuclear cells, mesenchymal stem cells and embryonic stem cells [6]. Furthermore, the discovery and demonstration of a resident cardiac stem cell population that is capable of proliferating and differentiating into cardiomyocytes has further challenged the traditional belief that heart is incapable of regenerating itself [7].

\section{Stem cell technology}

Recent developments in stem cell biology have elucidated a significant differentiation plasticity of both embryonic and adult stem cells in human tissue. These findings have ignited the hopes of achieving cell-based replacement therapy for cardiovascular disease. Stem cells with potential applications in the treatment of cardiovascular disease can be obtained from a variety of sources including the blood, bone marrow, somatic cells, and within the heart itself.

The clinical trials that have been performed in patients with AMI, chronic ischemic heart failure and dilated cardiomyopathy have proven the safety and efficacy of stem cell therapy in vivo with varying degrees of success [6,8-16]. This review will provide an overview of these studies and we will also discuss possible mechanisms behind successful cardiac stem cell therapy.

\section{Embryonic stem cells}

Embryonic stem cells (ESCs) are pluripotent stem cells derived from the blastocyst stage. These cells are able to differentiate into cells of all three embryonic germ layers [17]. Differentiation of both mouse and human ESCs into cardiomyocytes has already been described in several studies $[18,19]$. Furthermore, there has been a demonstrated functional improvement of infarcted myocardium of rodents after transplantation with ESCs [20-25]. These administrated ESCs have the capacity to become engrafted, propagate action potentials, and improve left ventricular (LV) function through positive LV remodeling in animal models $[24,26,29]$.

Although animal models of ESC therapy have produced exciting results, human applications of ESCs have proceeded cautiously. Factors that have limited further research on ESCs in the clinical arena include concerns about: the possibility of immune rejection of allotransplanted cells, low yield of cardiomyocytes, and risk of teratoma formation [30,31].

\section{Induced pluripotent stem cells}

Induced pluripotent stem (iPS) cells have been introduced as an alternative to ESCs. These cells arise from somatic cells that have been reprogrammed to an embryonic-like state [32-35]. The reprogramming occurs by insertion of a defined set of transcription factors that leads to

*Corresponding author: Palak Shah, MD, Division of Cardiology, Medical Faculty Associates, Suite 4-417, 2150 Pennsylvania Avenue NW, Washington DC 20037 E-mail: palak@gwu.edu

Received September 15, 2011; Accepted November 02, 2011; Published November 04, 2011

Citation: Sadri S, Mazhari R, Sadri M, Konjedi N, Shah P, (2011) Cardiovascular Applications of Stem Cell Therapy. J Stem Cell Res Ther S1:003. doi:10.4172/21577633.S1-003

Copyright: ( 2011 Sadri S, et al. This is an open-access article distributed under the terms of the Creative Commons Attribution License, which permits unrestricted use, distribution, and reproduction in any medium, provided the original author and source are credited. 
the expression of embryonic stem cell factors including: OCT4, SOX2, c-Myc, KLF4, NANOG and LIN28 [33,34]. iPS cells might be an ideal source for cell-based therapy because they can directly be derived from the patient requiring therapy, without concerns for immune-mediated rejection [35]. These cells are also capable of forming all three cell types that exist within the heart: endothelial cells, smooth muscle cells, and functional cardiomyocytes [36-39].

Although iPS cells have a robust potential to replace ESCs and revolutionize cardiovascular stem cell-based therapies, concerns regarding their wide spread use include: poor cardiomyocyte differentiation, potential for tumorigenesis and some suggestion that the resultant cardiomyocytes maybe inefficient [39-41]. Human iPS lines exhibit broad epigenetic diversity which may limit their cardiac differentiation potential $[39,42]$. With regards to tumorigenesis, there is laboratory evidence that the epigenetic memory of the somatic cell of origin can influence the differentiation potential of iPS cells into tumor cells [43]. Another limitation of iPS cells is concern that the generation of iPS cells using retroviruses or lentiviruses, has the potential for insertional mutagenesis that can lead to malignant transformation following cardiac differentiation [44].

\section{Bone marrow cells}

A variety of cells within the bone marrow have demonstrated the plasticity to form cardiac myocytes, collectively they are known as bone marrow cells (BMCs). Orlic et al. showed that BMCs transplanted into the infarcted myocardium of rodents can differentiate into cardiomyocytes and improve cardiac function [45]. Two other groups went on to demonstrate the safety of intramyocardial injections of BMCs in patients with severe ischemic cardiomyopathy and AMI $[10,46]$. Both studies showed an improvement in left ventricular function and myocardial perfusion. The effect of BMC therapy on left ventricular function after acute myocardial infarction (AMI) was tested in the BOOST trial (bone marrow transfer to enhance ST-elevation infarct regeneration) [9]. Sixty patients, who presented with ST-segment elevation MI and underwent successful primary percutaneous coronary intervention (PCI) with stent placement, were then randomized to receive intracoronary infusion of autologous BMCs versus standard care alone. Patients in the BMC group showed significant improvements in left ventricular function compared with the control group six months after stem cell transplantation [9]. Although, this reported change in left ventricular ejection fraction (LVEF) was no longer apparent at 18 months follow-up [47]. The paradox at 18 month follow-up has been explained by two subsequent studies. Ballsam et al. studied the ability of injected c-kit-enriched BMCs to regenerate myocardium in a mice infarct model. They demonstrated that transplanted BMCs express the hematopoietic marker CD45 and myeloid marker Gr-1 and develop into hematopoietic cells within the myocardium rather than cardiomyocytes $[48,49]$. Murry et al. also demonstrated that transplanted bone marrow derived hematopoietic stem cells failed to transdifferentiate into cardiomyocytes in the hearts of mice. These studies indicate that BMCs do not readily acquire a cardiac phenotype, and raise a cautionary note for clinical studies of infarct repair [49].

\section{Mesenchymal stem cells}

Mesenchymal stem cells (MSCs) are a group of clonogenic cells that exist in multiple locations within the human body including: bone marrow stroma, peripheral blood, umbilical cord, adipose tissue, fetal liver, lung, synovial membrane and dental pulp [50-56]. Due to their ease of isolation, wide differentiation potential, and lack of immunogenicity; MSCs have been utilized in clinical medicine for a variety of application [57-61].

Human bone marrow-derived mesenchymal stem cells (BMSCs), or multipotent mesenchymal stromal cells, are a group of clonogenic cells present among the bone marrow stroma that are capable of multi-lineage differentiation [62]. BMSCs can be used to generate cardiomyocytes for use in a range of cardiovascular diseases [63,64]. Makino and colleagues have successfully induced BMSCs to differentiate into cardiomyocytes in vitro with 5-azacytidine [65]. Amado et al. demonstrated improved myocardial thickness, enhanced contractility and reduced scar formation in the infarct zone of a post-MI animal model [66]. In a swine model of chronic ischemic cardiomyopathy, Hare and his group reported the capacity of allogeneic BMSCs to engraft and differentiate into cardiomyocytes, smooth muscle cells and endothelium [67]. They injected male BMSCs into female swine and identified these cells within the myocardium by co-localization of the Y-chromosome by fluorescence in situ hybridization. They showed that cardiomyocyte differentiation was present in approximately $14 \%$ of Y-positive BMSCs as identified by co-staining for the cardiac structural proteins $\alpha$-sarcomeric actinin, tropomyosin, GATA-4 and Nkx2.5. In addition, differentiated myocytes exhibited the capacity for coupling with host myocytes via connexin- 43 and had the ability to promote angiogenesis as well [67].

Based on these pre-clinical studies, early stage clinical trials with intravenous, intracoronary and intramyocardial delivery of MSCs have been conducted [68-70]. In a randomized evaluation of intravenous allogeneic MSCs versus placebo, Hare et al. showed that this form of cell therapy was safe in post-MI patients with an improvement in ejection fraction by echocardiography of $6 \%$ at 3 months for patients receiving intravenous MSCs [68]. Intramyocardial injection of MSCs was also recently studied in 8 patients with a chronic ischemic cardiomyopathy. This study demonstrated an overall improvement in regional contractility which strongly correlated with a reduction in both the end-diastolic and end-systolic volumes [69].

\section{Skeletal myoblasts}

Cell-based cardiac repair has been studied with the transplantation of autologously derived skeletal myoblasts [71-76]. Several clinical studies have been performed based on the fact that these cells can readily be harvested from the patient, proliferated in vitro and then be reintroduced to the patient without a need for immunosuppression as they are autologously derived [71,77-79].

A variety of preclinical and clinical studies have demonstrated that engrafted skeletal myoblasts transdifferentiate into cardiomyocytes and result in functional improvement [71,75,78-81]. There are however, conflicting views regarding the utility of skeletal myoblasts in treating cardiomyopathy patients. These include their commitment to their skeletal muscle lineage and perhaps more importantly their failure to electromechanically couple with cardiomyocytes which can lead to malignant ventricular arrhythmias [76-82]. Indeed, the ventricular arrhythmias arising from the lack of electromechanical integration represents a major problem facing skeletal myoblast transplantation [83-85]. 


\section{Endothelial progenitor cells}

Endothelial progenitor cells (EPCs) are either bone marrow derived or found circulating in the peripheral blood [86]. They express AC133 and other endothelial cell surface markers [87-89]. Endothelial cells have a pivotal role in the efficient development and function of cardiovascular tissue [90]. In addition, their role in the development of mature endothelium is key as the endothelium mediates angiogenesis, inflammation, vasculogenesis and thrombosis [91].

Given the EPCs ability to self-renew and their potential application in myocardial repair after AMI, EPCs have received significant research attention [92,93]. For instance, when EPCs are injected into animal models of ischemia, they rapidly incorporate into new sites of vascularization $[92,94]$. Their role in neoangiogenesis results in decreased apoptosis of hypertrophied myocytes, long-term salvage and survival of viable myocardium and a reduction in collagen deposition that leads to a sustained improvement in cardiac function [95].

\section{Cardiac stem cells}

Over the past few decades stem cells have been characterized and isolated from many adult tissues. Despite this, the search for cardiac stem cells (CSCs) has been considered unprofitable until recently. This is because of a traditionally accepted paradigm in cardiac biology that considered the human heart as a post-mitotic and terminally differentiated organ with no intrinsic regenerative capacity [96-98]. This belief, however, has been challenged recently with evidence of cardiac cell division after AMI and through the identification of stem cell-like cells within the heart. These cells appear to have the potential to regenerate contractile cardiomyocytes and restore the normal coronary vascular bed $[5,99]$.

The differentiation potential of stem cell-like cells isolated from the heart has been studied both in vitro and in vivo [7]. These studies have demonstrated that these undifferentiated stem cell-like cells express stem cell markers, such as c-kit or Sca1 [100]. These cells which originate from the endomyocardium have the ability to proliferate and differentiate into cardiomyocytes, smooth muscle cells and endothelial cells [7,101-104].

The isolation and characterization of the CSCs give us an opportunity to explain and explore the regenerative capacity of the heart and ignites the hope that in the near future we might be able to manipulate these human CSCs to hone to the regions of damaged myocardium and promote cardiac repairs that regenerate functional myocardium. Similar work has already been done in the rodent myocardium $[105,106]$. However, the rarity of CSCs coupled with their complex isolation procedure presents a significant challenge to the widespread clinical application of CSCs.

\section{Mechanisms of action}

Almost all cell-based therapies have demonstrated an improvement of left ventricular function and ameliorated adverse cardiac remodeling, yet the mechanism behind the benefit of stem cell therapy is not fully understood [107]. Suggested mechanisms of stem cell benefit include: transdifferentiation into the various cellular constituents of the heart; fusion with other cardiac cells; incorporation and integration of implanted stem cells into native myocardial fibers; neovascularization; production of paracrine factors; and activation of endogenous repair mechanisms [92,93,101,102,107-113].
Transdifferentiation is the most common mechanism behind cardiac regeneration and this refers to the process by which stem cells adopt the characteristics of their surrounding tissues. Several animal and clinical studies have indicated that those stem cells transplanted into infarcted myocardium differentiate into new cardiomyocytes, endothelial cells and smooth muscle cells [45,49,64,65,114-116]. Transdifferentiation as a proposed mechanism for cardiac repair has been challenged by other groups and continues to remain a controversial issue $[48,49,117]$. Fusion of the administrated cells with host cells is another proposed mechanism of stem cell benefit. Cell fusion results when there is a transfer of cell contents, including genetic material from transplanted cells into host cells [118-120]. Several studies conducted in mice and pig models have demonstrated that BMCs engrafted into the myocardium, fuse with host cardiomyocytes [121,122]. Other animal studies proposed mechanisms by which stem cell therapy may have beneficial effects including the secretion of paracrine factors that have both anti-apoptotic and neoangiogenic properties [122-124].

Neovascularization leads to the formation of new blood vessels and improves perfusion to the infarcted myocardium; thus limiting apoptosis within these areas. Neovascularization as a result of BMSCs and BMCs is postulated to occur because these cells secrete angiogenic factors like vascular endothelial growth factor, fibroblast growth factor, hepatocyte growth factor and angioprotein-1 [94,125-128]. Also, BMSCs secrete some cytokines and growth factors including interleukin-1, interleukin-6, tumor necrosis factor- $\alpha$ and transforming growth factor- $\beta$ that play a pivotal role in the tissue response to injury [125].

Finally, the recent identification of CSCs and their potential for myocardial and vascular regeneration raises the possibility that these cells may be activated by other stem cells to promote endogenous myocardial repair $[5,7,99,102]$. This is supported by a recent study that shows that bone marrow derived c-kit $(+)$ cells stimulate endogenous cardiomyocyte progenitors and promote cardiac repair [129]. Thus, stimulation of endogenous cardiogenic progenitor activity appears to be a critical mechanism of cardiac stem cell therapy [129].

\section{The future of cardiac stem cell therapy}

The prospect of cell-based therapies for cardiovascular disease has led to excitement within the scientific community as cardiovascular disease continues to be the leading cause of death worldwide. There is a growing body of evidence from both the basic sciences as well as through translational studies that prove the ability of stem cells to improve left ventricular function. There are however, some critical questions regarding cardiac stem cell therapy that remain to be answered. These include: what is the best class of stem cells for cardiac cell therapy; what is the mechanism of benefit underlying cardiac stem cell therapies; what is the best vehicle for delivery of these cells into the myocardium; how can we activate resident CSCs and finally how can we promote engraftment and incorporation of transplanted stem cells within the heart? To help answer these questions and promote the future of cardiac stem cell-based therapies we need to continue to foster collaboration between basic scientists and clinical researchers. Such a partnership will help us understand how cardiac stem cell-based therapies can be optimized to guide future clinical studies. Finally, if we can promote an environment that facilitates stem cells to successfully repair and regenerate the heart, we can expect to see resultant 
Citation: Sadri S, Mazhari R, Sadri M, Konjedi N, Shah P, (2011) Cardiovascular Applications of Stem Cell Therapy. J Stem Cell Res Ther S1:003. doi:10.4172/2157-7633.S1-003

improvements in myocardial function, with clinical benefit to follow.

\section{References}

1. Lloyd-Jones DM, Larson MG, Leip EP, Beiser A, D'Agostino RB, et al. (2002) Lifetime risk for developing congestive heart failure: the Framingham Heart Study. Circulation $106:$ 3068-3072.

2. Roger VL, Go AS, Lloyd-Jones DM, Adams RJ, Berry JD, et al. (2011) Heart Disease and Stroke Statistics-2011 Update A Report From the American Heart Association. Circulation 123: E18-E209.

3. Juenger J, Schellberg D, Kraemer S, Haunstetter A, Zugck C, et al. (2002) Health related quality of life in patients with congestive heart failure: comparison with other chronic diseases and relation to functional variables. Heart 87: 235 241

4. Hobbs FD, Kenkre JE, Roalfe AK, Davis RC, Hare R, et al. (2002) Impact of heart failure and left ventricular systolic dysfunction on quality of life: a crosssectional study comparing common chronic cardiac and medical disorders and a representative adult population. Eur Heart J 23: 1867-1876

5. Beltrami AP, Urbanek K, Kajstura J, Yan SM, Finato N, et al. (2001) Evidence that human cardiac myocytes divide after myocardial infarction. $\mathrm{N}$ Engl J Med 344: $1750-1757$

6. Mozid AM, Arnous S, Sammut EC, Mathur A (2011) Stem cell therapy for heart diseases. Br Med Bull 98: 143-159.

7. Beltrami AP, Barlucchi L, Torella D, Baker M, Limana F, et al. (2003) Adult cardiac stem cells are multipotent and support myocardial regeneration. Cell 114: 763-776.

8. Assmus B, Schächinger V, Teupe C, Britten M, Lehmann R, et al. (2002) Transplantation of Progenitor Cells and Regeneration Enhancement in Acute Myocardial Infarction (TOPCARE-AMI). Circulation 106: 3009-3017.

9. Wollert KC, Meyer GP, Lotz J, Ringes-Lichtenberg S, Lippolt P, et al. (2004) Intracoronary autologous bone-marrow cell transfer after myocardial infarction: the BOOST randomised controlled clinical trial. Lancet 364: 141-148.

10. Schachinger V, Erbs S, Elsässer A, Haberbosch W, Hambrecht R, et al. (2006) Intracoronary bone marrow-derived progenitor cells in acute myocardial infarction. N Engl J Med 355: 1210-1221.

11. Huikuri HV, Kervinen K, Niemelä M, Ylitalo K, Saily M, et al. (2008) Effects of intracoronary injection of mononuclear bone marrow cells on left ventricular function, arrhythmia risk profile, and restenosis after thrombolytic therapy of acute myocardial infarction. Eur Heart J 29: 2723-2732.

12. Dib N, Michler RE, Pagani FD, Wright S, Kereiakes DJ, et al. (2005) Safety and feasibility of autologous myoblast transplantation in patients with ischemic cardiomyopathy: four-year follow-up. Circulation 112: 1748-1755.

13. Dib N, Dinsmore J, Lababidi Z, White B, Moravec S, et al. (2009) One-year follow-up of feasibility and safety of the first U.S., randomized, controlled study using 3-dimensional guided catheter-based delivery of autologous skeletal myoblasts for ischemic cardiomyopathy (CAuSMIC study). JACC Cardiovasc Interv 2: 9-16.

14. Stamm C, Kleine HD, Choi YH, Dunkelmann S, Lauffs JA, et al. (2007) Intramyocardial delivery of CD133+ bone marrow cells and coronary artery bypass grafting for chronic ischemic heart disease: safety and efficacy studies. J Thorac Cardiovasc Surg 133: 717-725.

15. Assmus B, Honold J, Schächinger V, Britten MB, Fischer-Rasokat U, et al. (2006) Transcoronary transplantation of progenitor cells after myocardial infarction. N Engl J Med 355: 1222-1232.

16. Strauer BE, Yousef M, Schannwell CM (2010) The acute and long-term effects of intracoronary Stem cell Transplantation in 191 patients with chronic heARt failure: the STAR-heart study. Eur J Heart Fail 12: 721-729.

17. Solter D (2006) From teratocarcinomas to embryonic stem cells and beyond: a history of embryonic stem cell research. Nat Rev Genet 7: 319-327.

18. Christoforou N, Gearhart JD (2007) Stem cells and their potential in cell-based cardiac therapies. Prog Cardiovasc Dis 49: 396-413.
19. Xu C, Police S, Rao N, Carpenter MK (2002) Characterization and enrichmen of cardiomyocytes derived from human embryonic stem cells. Circ Res 91: 501 508

20. Hodgson DM, Behfar A, Zingman LV, Kane GC, Perez-Terzic C, et al. (2004) Stable benefit of embryonic stem cell therapy in myocardial infarction. Am J Physiol Heart Circ Physiol 287: H471-H479.

21. Min JY, Yang Y, Converso KL, Liu L, Huang Q, et al. (2002) Transplantation of embryonic stem cells improves cardiac function in postinfarcted rats. J App Physiol 92: 288-296.

22. Min JY, Yang Y, Sullivan MF, Ke Q, Converso KL, et al. (2003) Long-term improvement of cardiac function in rats after infarction by transplantation of embryonic stem cells. J Thorac Cardiovasc Surg 125: 361-369.

23. Klug MG, Soonpaa MH, Koh GY, Field LJ (1996) Genetically selected cardiomyocytes from differentiating embronic stem cells form stable intracardiac grafts. J Clin Invest 98: 216-224.

24. Singla DK, Hacker TA, Ma L, Douglas PS, Sullivan R, et al. (2006) Transplantation of embryonic stem cells into the infarcted mouse heart: formation of multiple cell types. J Mol Cell Cardiol 40: 195-200.

25. Min JY, Huang X, Xiang M, Meissner A, Chen Y, et al. (2006) Homing of intravenously infused embryonic stem cell-derived cells to injured hearts after myocardial infarction. J Thorac Cardiovasc Surg 131: 889-897.

26. Kehat I, Khimovich L, Caspi O, Gepstein A, Shofti R, et al. (2004) Electromechanical integration of cardiomyocytes derived from human embryonic stem cells. Nat Biotechnol 22: 1282-1289.

27. Kehat I, Kenyagin-Karsenti D, Snir M, Segev H, Amit M, et al. (2001) Human embryonic stem cells can differentiate into myocytes with structural and functional properties of cardiomyocytes. J Clin Invest 108: 407-414.

28. Marchetti S, Gimond C, Iljin K, Bourcier C, Alitalo K, et al. (2002) Endothelia cells genetically selected from differentiating mouse embryonic stem cells incorporate at sites of neovascularization in vivo. J Cell Sci 115: 2075-2085.

29. Behfar A, Zingman LV, Hodgson DM, Rauzier JM, Kane GC, et al. (2002) Stem cell differentiation requires a paracrine pathway in the heart. FASEB $\mathrm{J} 16$ 1558-1566.

30. Lee AS, Tang C, Cao F, Xie X, van der Bogt K, et al. (2009) Effects of cell number on teratoma formation by human embryonic stem cells. Cell Cycle 8 : 2608-2612.

31. Thomson JA, Itskovitz-Eldor J, Shapiro SS, Waknitz MA, Swiergiel JJ, et al (1998) Embryonic stem cell lines derived from human blastocysts. Science 282: $1145-1147$

32. Aasen T, Raya A, Barrero MJ, Garreta E, Consiglio A, et al. (2008) Efficient and rapid generation of induced pluripotent stem cells from human keratinocytes. Nat Biotechnol 26: 1276-1284.

33. Takahashi K, Yamanaka S (2006) Induction of pluripotent stem cells from mouse embryonic and adult fibroblast cultures by defined factors. Cell 126 663-676.

34. Takahashi K, Yamanaka S (2007) Induction of pluripotent stem cells from adult human fibroblasts by defined factors. Cell 131: 861-872.

35. Nishikawa S, Goldstein RA, Nierras CR (2008) The promise of human induced pluripotent stem cells for research and therapy. Nat Rev Mol Cell Biol 9: 725 729.

36. Schenke-Layland K, Rhodes KE, Angelis E, Butylkova Y, Heydarkhan-Hagvall $\mathrm{S}$, et al. (2008) Reprogrammed mouse fibroblasts differentiate into cells of the cardiovascular and hematopoietic lineages. Stem Cells 26: 1537-1546.

37. Mauritz C, Schwanke K, Reppel M, Neef S, Katsirntaki K, et al. (2008) Generation of functional murine cardiac myocytes from induced pluripotent stem cells. Circulation 118: 507-517.

38. Narazaki G, Uosaki H, Teranishi M, Okita K, Kim B, et al. (2008) Directed and systematic differentiation of cardiovascular cells from mouse induced pluripotent stem cells. Circulation 118: 498-506.

39. Zhang J, Wilson GF, Soerens AG, Koonce CH, Yu J, et al. (2009) Functiona 
cardiomyocytes derived from human induced pluripotent stem cells. Circ Res 104: e30-41.

40. Chun YS, Chaudhari P, Jang YY (2010) Applications of patient-specific induced pluripotent stem cells; focused on disease modeling, drug screening and therapeutic potentials for liver disease. Int J Biol Sci 6: 796-805

41. Burridge PW, Thompson S, Millrod MA, Weinberg S, Yuan X, et al. (2011) A universal system for highly efficient cardiac differentiation of human induced pluripotent stem cells that eliminates interline variability. PLoS One 6: e18293.

42. Kim K, Doi A, Wen B, Ng K, Zhao R, et al. (2010) Epigenetic memory in induced pluripotent stem cells. Nature 467: 285-290.

43. Tong M, Lv Z, Liu L, Zhu H, Zheng QY, et al. (2011) Mice generated from tetraploid complementation competent iPS cells show similar developmenta features as those from ES cells but are prone to tumorigenesis. Cell Res 21 1634-1637.

44. Lowry WE, Quan WL (2010) Roadblocks en route to the clinical application of induced pluripotent stem cells. J Cell Sci 123: 643-651.

45. Orlic D, Kajstura J, Chimenti S, Limana F, Jakoniuk I, et al. (2001) Mobilized bone marrow cells repair the infarcted heart, improving function and survival. Proc Natl Acad Sci U S A 98: 10344-10349.

46. Perin EC, Dohmann HF, Borojevic R, Silva SA, Sousa AL, et al. (2003) Transendocardial, autologous bone marrow cell transplantation for severe chronic ischemic heart failure. Circulation 107: 2294-2302.

47. Meyer GP, Wollert KC, Lotz J, Steffens J, Lippolt P, et al. (2006) Intracoronary bone marrow cell transfer after myocardial infarction: eighteen months' followup data from the randomized, controlled BOOST (BOne marrOw transfer to enhance ST-elevation infarct regeneration) trial. Circulation 113: 1287-1294.

48. Balsam LB, Wagers AJ, Christensen JL, Kofidis T, Weissman IL, et al. (2004) Haematopoietic stem cells adopt mature haematopoietic fates in ischaemic myocardium. Nature 428: 668-673.

49. Murry CE, Soonpaa MH, Reinecke H, Nakajima H, Nakajima HO, et al. (2004) Haematopoietic stem cells do not transdifferentiate into cardiac myocytes in myocardial infarcts. Nature 428: 664-668.

50. De Bari C, Dell'Accio F, Tylzanowski P, Luyten FP (2001) Multipotent mesenchymal stem cells from adult human synovial membrane. Arthritis Rheum 44: 1928-1942.

51. in 't Anker PS, Noort WA, Scherjon SA, Kleijburg-van der Keur C, Kruisselbrink AB, et al. (2003) Mesenchymal stem cells in human second-trimester bone marrow, liver, lung, and spleen exhibit a similar immunophenotype but a heterogeneous multilineage differentiation potential. Haematologica 88: 845852.

52. Campagnoli C, Roberts IA, Kumar S, Bennett PR, Bellantuono I, et al. (2001) Identification of mesenchymal stem/progenitor cells in human first-trimester fetal blood, liver, and bone marrow. Blood 98: 2396-2402.

53. Gronthos S, Franklin DM, Leddy HA, Robey PG, Storms RW, et al. (2001) Surface protein characterization of human adipose tissue-derived stromal cells. J Cell Physiol 189: 54-63.

54. Rosada C, Justesen J, Melsvik D, Ebbesen P, Kassem M (2003) The human umbilical cord blood: a potential source for osteoblast progenitor cells. Calcif Tissue Int 72: 135-142.

55. Kuznetsov SA, Mankani MH, Gronthos S, Satomura K, Bianco P, et al. (2001) Circulating skeletal stem cells. J Cell Biol 153: 1133-1140.

56. Otaki S, Ueshima S, Shiraishi K, Sugiyama K, Hamada S, et al. (2007) Mesenchymal progenitor cells in adult human dental pulp and their ability to form bone when transplanted into immunocompromised mice. Cell Biol Int 31: 1191-1197.

57. Ankrum J, Karp JM (2010) Mesenchymal stem cell therapy: Two steps forward, one step back. Trends Mol Med 16: 203-209.

58. Aggarwal S, Pittenger MF (2005) Human mesenchymal stem cells modulate allogeneic immune cell responses. Blood 105: 1815-1822.

59. Pittenger MF, Martin BJ (2004) Mesenchymal stem cells and their potential as cardiac therapeutics. Circ Res 95: 9-20.
60. Bianco P, Riminucci M, Gronthos S, Robey PG (2001) Bone marrow stroma stem cells: nature, biology, and potential applications. Stem Cells 19: 180-192

61. Djouad F, Bony C, Häupl T, Uzé G, Lahlou N, et al. (2005) Transcriptional profiles discriminate bone marrow-derived and synovium-derived mesenchymal stem cells. Arthritis Res Ther 7: R1304-1315

62. Dominici M, Le Blanc K, Mueller I, Slaper-Cortenbach I, Marini F, et al. (2006) Minimal criteria for defining multipotent mesenchymal stromal cells. The International Society for Cellular Therapy position statement. Cytotherapy 8 : 315-317.

63. Liechty KW, MacKenzie TC, Shaaban AF, Radu A, Moseley AM, et al. (2000) Human mesenchymal stem cells engraft and demonstrate site-specific differentiation after in utero transplantation in sheep. Nat Med 6: 1282-1286.

64. Toma C, Pittenger MF, Cahill KS, Byrne BJ, Kessler PD (2002) Human mesenchymal stem cells differentiate to a cardiomyocyte phenotype in the adult murine heart. Circulation 105: 93-98.

65. Makino S, Fukuda K, Miyoshi S, Konishi F, Kodama H, et al. (1999) Cardiomyocytes can be generated from marrow stromal cells in vitro. $\mathrm{J}$ Clin Invest 103: 697-705.

66. Amado LC, Saliaris AP, Schuleri KH, St John M, Xie JS, et al. (2005) Cardiac repair with intramyocardial injection of allogeneic mesenchymal stem cells after myocardial infarction. Proc Natl Acad Sci U S A 102: 11474-11479.

67. Quevedo HC, Hatzistergos KE, Oskouei BN, Feigenbaum GS, Rodriguez JE, et al. (2009) Allogeneic mesenchymal stem cells restore cardiac function in chronic ischemic cardiomyopathy via trilineage differentiating capacity. Proc Natl Acad Sci U S A 106: 14022-14027.

68. Hare JM, Traverse JH, Henry TD, Dib N, Strumpf RK, et al. (2009) A Randomized, Double-Blind, Placebo-Controlled, Dose-Escalation Study of Intravenous Adult Human Mesenchymal Stem Cells (Prochymal) After Acute Myocardial Infarction. J Am Coll Cardiol 54: 2277-2286.

69. Williams AR, Trachtenberg B, Velazquez DL, McNiece I, Altman P, et al. (2011) Intramyocardial Stem Cell Injection in Patients With Ischemic Cardiomyopathy Functional Recovery and Reverse Remodeling. Circulation Research 108: 792 796.

70. Chen SL, Fang WW, Ye F, Liu YH, Qian J, et al. (2004) Effect on left ventricular function of intracoronary transplantation of autologous bone marrow mesenchymal stem cell in patients with acute myocardial infarction. American Journal of Cardiology 94: 92-95

71. Murry CE, Wiseman RW, Schwartz SM, Hauschka SD, et al. (1996) Skeleta myoblast transplantation for repair of myocardial necrosis. J Clin Invest 98 : 2512-2523.

72. Chiu RC, Zibaitis A, Kao RL (1995) Cellular cardiomyoplasty: myocardia regeneration with satellite cell implantation. Ann Thorac Surg 60: 12-18.

73. Yoon PD, Kao RL, Magovern GJ (1995) Myocardial regeneration. Transplanting satellite cells into damaged myocardium. Tex Heart Inst J 22: 119-125.

74. Atkins BZ, Lewis CW, Kraus WE, Hutcheson KA, Glower DD, et al., (1999) Intracardiac transplantation of skeletal myoblasts yields two populations of striated cells in situ. Ann Thorac Surg 67: 124-129.

75. Taylor DA, Atkins BZ, Hungspreugs $P$, Jones TR, Reedy MC, et al. (1998) Regenerating functional myocardium: improved performance after skeleta myoblast transplantation. Nat Med 4: 929-933

76. Reinecke H, MacDonald GH, Hauschka SD, Murry CE (2000) Electromechanical coupling between skeletal and cardiac muscle. Implications for infarct repair. J Cell Biol 149: 731-740

77. Ince H, Petzsch M, Rehders TC, Chatterjee T, Nienaber CA (2004) Transcathete transplantation of autologous skeletal myoblasts in postinfarction patients with severe left ventricular dysfunction. J Endovasc Ther 11: 695-704.

78. Menasche P, Hagège AA, Vilquin JT, Desnos M, Abergel E, et al. (2003) Autologous skeletal myoblast transplantation for severe postinfarction left ventricular dysfunction. J Am Coll Cardiol 41: 1078-1083.

79. Pagani FD, DerSimonian H, Zawadzka A, Wetzel K, Edge AS, et al. (2003) Autologous skeletal myoblasts transplanted to ischemia-damaged myocardium 
Citation: Sadri S, Mazhari R, Sadri M, Konjedi N, Shah P, (2011) Cardiovascular Applications of Stem Cell Therapy. J Stem Cell Res Ther S1:003. doi:10.4172/2157-7633.S1-003

Page 6 of 7

in humans. Histological analysis of cell survival and differentiation. J Am Coll Cardiol 41: 879-888.

80. Ghostine S, Carrion C, Souza LC, Richard P, Bruneval P, et al. (2002) Longterm efficacy of myoblast transplantation on regional structure and function after myocardial infarction. Circulation 106: I131-136.

81. Durrani S, Konoplyannikov M, Ashraf M, Haider KH, et al. (2010) Skeletal myoblasts for cardiac repair. Regenerative Medicine 5: 919-932.

82. Menasche P, Alfieri O, Janssens S, McKenna W, Reichenspurner $\mathrm{H}$, et al (2008) The Myoblast Autologous Grafting in Ischemic Cardiomyopathy (MAGIC) trial: first randomized placebo-controlled study of myoblast transplantation. Circulation 117: 1189-1200

83. Abraham MR, Hare JM (2006) Is skeletal myoblast transplantation proarrhythmic? The jury is still out. Heart Rhythm 3:462-463.

84. Fouts K, Fernandes B, Mal N, Liu J, Laurita KR, et al. (2006) Electrophysiological consequence of skeletal myoblast transplantation in normal and infarcted canine myocardium. Heart Rhythm 3: 452-461.

85. Eisen HJ (2008) Skeletal myoblast transplantation: no MAGIC bullet for ischemic cardiomyopathy. Nat Clin Pract Cardiovasc Med 5: 520-521.

86. Young PP, Vaughan DE, Hatzopoulos AK (2007) Biologic properties of endothelial progenitor cells and their potential for cell therapy. Prog Cardiovasc Dis 49: 421-429

87. Yin AH, Miraglia S, Zanjani ED, Almeida-Porada G, Ogawa M, et al. (1997) AC133, a novel marker for human hematopoietic stem and progenitor cells. Blood 90: 5002-5012.

88. Eichmann A, Corbel C, Nataf V, Vaigot P, Bréant C, et al. (1997) Liganddependent development of the endothelial and hemopoietic lineages from embryonic mesodermal cells expressing vascular endothelial growth factor receptor 2. Proc Natl Acad Sci U S A 94: 5141-5146.

89. Sato TN, Qin Y, Kozak CA, Audus KL (1993) Tie-1 and tie-2 define another class of putative receptor tyrosine kinase genes expressed in early embryonic vascular system. Proc Natl Acad Sci U S A 90: 9355-9358.

90. Zwerts F, Lupu F, De Vriese A, Pollefeyt S, Moons L, et al. (2007) Lack of endothelial cell survivin causes embryonic defects in angiogenesis, cardiogenesis, and neural tube closure. Blood 109: 4742-4752.

91. Yu Y, Flint AF, Mulliken JB, Wu JK, Bischoff J (2004) Endothelial progenitor cells in infantile hemangioma. Blood 103: 1373-1375

92. Kocher AA, Schuster MD, Szabolcs MJ, Takuma S, Burkhoff D, et al. (2001) Neovascularization of ischemic myocardium by human bone-marrow-derived angioblasts prevents cardiomyocyte apoptosis, reduces remodeling and improves cardiac function. Nat Med 7: 430-436.

93. Schuster MD, Kocher AA, Seki T, Martens TP, Xiang G, et al. (2004) Myocardia neovascularization by bone marrow angioblasts results in cardiomyocyte regeneration. Am J Physiol Heart Circ Physiol 287: H525-532.

94. Asahara T, Masuda H, Takahashi T, Kalka C, Pastore C, et al. (1999) Bone marrow origin of endothelial progenitor cells responsible for postnatal vasculogenesis in physiological and pathological neovascularization. Circ Res 85: 221-228.

95. Itescu S, Kocher AA, Schuster MD, Szabolcs MJ, Takuma S, et al. (2001) Neovascularization of ischemic myocardium by human bone-marrow-derived angioblasts prevents cardiomyocyte apoptosis, reduces remodeling and improves cardiac function. Nat Med 7: 430-436.

96. Pasumarthi KB, Field LJ (2002) Cardiomyocyte cell cycle regulation. Circ Res 90: 1044-1054

97. Chien KR, Olson EN (2002) Converging pathways and principles in heart development and disease: CV@CSH. Cell 110: 153-162.

98. Rosenthal N (2003) Prometheus's vulture and the stem-cell promise. N Engl J Med 349: 267-274

99. Quaini F,Urbanek K, Beltrami AP, Finato N, Beltrami CA, et al. (2002) Chimerism of the transplanted heart. N Engl J Med 346: 5-15
100. Anversa P, Bearzi C, Rota M, Hosoda T, Tillmanns J, et al. (2007) Human cardiac stem cells. Proc Natl Acad Sci U S A 104:14068-14073.

101. Messina E, De Angelis L, Frati G, Morrone S, Chimenti S, et al. (2004) Isolation and expansion of adult cardiac stem cells from human and murine heart. Circ Res 95: 911-921.

102. Oh H, Bradfute SB, Gallardo TD, Nakamura T, Gaussin V, et al. (2003) Cardiac progenitor cells from adult myocardium: homing, differentiation, and fusion after infarction. Proc Natl Acad Sci U S A 100: 12313-12318.

103. Matsuura K, Nagai T, Nishigaki N, Oyama T, Nishi J, et al. (2004) Adult cardiac Sca-1-positive cells differentiate into beating cardiomyocytes. J Biol Chem 279: 11384-11391.

104. Kajstura J, Urbanek K, Perl S, Hosoda T, Zheng H, et al. (2010) Cardiomyogenesis in the adult human heart. Circ Res 107: 305-315.

105. Scorsin M, Hagege AA, Marotte F, Mirochnik N, Copin H, et al. (1997) Does transplantation of cardiomyocytes improve function of infarcted myocardium? Circulation 96: II-188-193.

106. Torella D, Ellison GM, Méndez-Ferrer S, Ibanez B, Nadal-Ginard B (2006) Resident human cardiac stem cells: role in cardiac cellular homeostasis and potential for myocardial regeneration. Nat Clin Pract Cardiovasc Med 3: S813.

107. Mazhari R, Hare JM (2007) Mechanisms of action of mesenchymal stem cells in cardiac repair: potential influences on the cardiac stem cell niche. Nat Clin Pract Cardiovasc Med 4: S21-26.

108. Moore HC, Mick R, Solin LJ, Sickles C, Mangan PA, et al. (1999) Autologous stem-cell transplant after conventional dose adjuvant chemotherapy for highrisk breast cancer: impact on the delivery of local-regional radiation therapy. Ann Oncol 10: 929-936

109. Nygren JM, Jovinge S, Breitbach M, Säwén P, Röll W, et al. (2004) Bone marrow-derived hematopoietic cells generate cardiomyocytes at a low frequency through cell fusion, but not transdifferentiation. Nat Med 10: 494501.

110. Gnecchi M, He H, Liang OD, Melo LG, Morello F, et al. (2005) Paracrine action accounts for marked protection of ischemic heart by Akt-modified mesenchymal stem cells. Nat Med 11: 367-368.

111. Noiseux N, Gnecchi M, Lopez-llasaca M, Zhang L, Solomon SD, et al. (2006) Mesenchymal stem cells overexpressing Akt dramatically repair infarcted myocardium and improve cardiac function despite infrequent cellular fusion or differentiation. Mol Ther 14: 840-850

112. Kajstura J, Rota M, Whang B, Cascapera S, Hosoda T, et al. (2005) Bone marrow cells differentiate in cardiac cell lineages after infarction independently of cell fusion. Circ Res 96: 127-137.

113. Condorelli G, Borello U, De Angelis L, Latronico M, Sirabella D, et al. (2001) Cardiomyocytes induce endothelial cells to trans-differentiate into cardiac muscle: implications for myocardium regeneration. Proc Natl Acad Sci U S A 98: 10733-10738.

114. Orlic D, Kajstura J, Chimenti S, Jakoniuk I, Anderson SM, et al. (2001) Bone marrow cells regenerate infarcted myocardium. Nature 410: 701-705.

115. Jackson KA, Majka SM, Wang H, Pocius J, Hartley CJ, et al. (2001) Regeneration of ischemic cardiac muscle and vascular endothelium by adult stem cells. J Clin Invest 107: 1395-1402.

116. Shake JG, Gruber PJ, Baumgartner WA, Senechal G, Meyers J, et al. (2002) Mesenchymal stem cell implantation in a swine myocardial infarct model: engraftment and functional effects. Ann Thorac Surg 73: 1919-1925.

117. Deten A, Volz HC, Clamors S, Leiblein S, Briest W, et al. (2005) Hematopoietic stem cells do not repair the infarcted mouse heart. Cardiovasc Res 65: 52-63.

118. Alvarez-Dolado M, Pardal R, Garcia-Verdugo JM, Fike JR, Lee HO, et al. (2003) Fusion of bone-marrow-derived cells with Purkinje neurons, cardiomyocytes and hepatocytes. Nature 425: 968-973.

119. Terada N, Hamazaki T, Oka M, Hoki M, Mastalerz DM, et al. (2002) Bone marrow cells adopt the phenotype of other cells by spontaneous cell fusion. Nature 416: 542-545 
Citation: Sadri S, Mazhari R, Sadri M, Konjedi N, Shah P, (2011) Cardiovascular Applications of Stem Cell Therapy. J Stem Cell Res Ther S1:003. doi:10.4172/2157-7633.S1-003

120. Ying QL, Nichols J, Evans EP, Smith AG (2002) Changing potency by spontaneous fusion. Nature 416: 545-548

121. Uemura R, Xu M, Ahmad N, Ashraf M (2006) Bone marrow stem cells prevent left ventricular remodeling of ischemic heart through paracrine signaling. Circ Res 98: 1414-1421

122. Fuchs S, Baffour R, Zhou YF, Shou M, Pierre A, et al. (2001) Transendocardial delivery of autologous bone marrow enhances collateral perfusion and regional function in pigs with chronic experimental myocardial ischemia. J Am Coll Cardiol 37: 1726-1732.

123. Takahashi T, Kalka C, Masuda H, Chen D, Silver M, et al. (1999) Ischemia- and cytokine-induced mobilization of bone marrow-derived endothelial progenitor cells for neovascularization. Nat Med 5: 434-438.

124. Iso Y, Spees JL, Serrano C, Bakondi B, Pochampally R, et al. (2007) Multipotent human stromal cells improve cardiac function after myocardial infarction in mice without long-term engraftment. Biochem Biophys Res Commun 354: 700-706.
125. Kinnaird T, Stabile E, Burnett MS, Lee CW, Barr S, et al. (2004) Marrowderived stromal cells express genes encoding a broad spectrum of arteriogenic cytokines and promote in vitro and in vivo arteriogenesis through paracrine mechanisms. Circ Res 94: 678-685.

126. Kinnaird T, Stabile E, Burnett MS, Shou M, Lee CW, et al. (2004) Loca delivery of marrow-derived stromal cells augments collateral perfusion through paracrine mechanisms. Circulation 109: 1543-1549.

127. Itescu S, Kocher AA, Schuster MD (2003) Myocardial neovascularization by adult bone marrow-derived angioblasts: strategies for improvement of cardiomyocyte function. Heart Fail Rev 8: 253-258.

128. Isner JM, Kalka C, Kawamoto A, Asahara T (2001) Bone marrow as a source of endothelial cells for natural and iatrogenic vascular repair. Ann N Y Acad Sci 953: 75-84.

129. Loffredo FS, Steinhauser ML, Gannon J, Lee RT (2011) Bone MarrowDerived Cell Therapy Stimulates Endogenous Cardiomyocyte Progenitors and Promotes Cardiac Repair. Cell Stem Cell 8: 389-398.
This article was originally published in a special issue, Cardiovascular Cell Therapy handled by Editor(s). Dr. Martin Rodriguez-Porcel, Medicine Mayo Medical School, USA; Dr. Rosalinda Madonna, USA 